\title{
BEHIND CLOSED DOORS: \\ SECRECY AND TRANSPARENCY IN THE TRANS-PACIFIC PARTNERSHIP TRADE NEGOTIATIONS
}

Sasha Maher ${ }^{1}$

\begin{abstract}
The Trans-Pacific Partnership (TPP) trade agreement has been mired in controversies about secrecy and the lack of transparency since the United States joined negotiations in 2010. Yet the content and impact of these disputes surrounding this new mega-regional trade agreement have not been explored. This article examines the role of secrecy in state formation by exploring the tension produced by the state's deliberate withholding of Trans-Pacific Partnership trade negotiation texts from public circulation ('TPP secret'). Focusing on how the TPP secret unfolded in New Zealand, where the Ministry for Foreign Affairs and Trade is the designated depository of the TPP texts, and criticism is prolific, I draw on the New Zealand High Court case that was filed by TPP critics against the Minister of Trade and on other commentary in order to trace the characteristics of the transparency debate. The article argues that the narrow focus of the debate on documents and procedures leaves critical questions about the militarisation of the Asia-Pacific and the security ambitions of the United States unanswered.
\end{abstract}

Keywords: secrecy; state formation; free trade agreements; transparency; neoliberalism

There's nothing innocent in making the visible invisible.

(Strathern 200ob, 209)

The role of secrecy in state formation is examined with reference to the tension surrounding the deliberate withholding of Trans-Pacific Partnership (TPP) ${ }^{2}$ trade negotiation texts from public circulation ('TPP secret'). I argue that the debate about releasing the texts worked to inadvertently affirm the efficacy of secrecy as a tool for state formation and has left unanswered important 
questions regarding the geostrategic implications that accompany the trade agreement.

The protests and widespread public criticism of the secrecy shrouding the TPP talks appeared to be a crisis of legitimacy for the twelve states involved in the talks. Military tropes about winning and losing the debates on consensus abounded, with states frequently represented on the losing side of the public battle. The containment and concealment of trade documents was said to demonstrate state illegitimacy, weakness, and corruption. According to this perspective, the state no longer served the nation's best interest: it had been captured by powerful multinational corporations. This distrustful subtext underwrote critics' calls for the TPP documents to be revealed. By presenting transparency as the end point, critics hoped to restore democracy.

I discuss the literature on state formation, secrecy, and transparency that informs my case study and contend that the state relies on secrecy as a political strategy. To work, secrecy needs an audience, an exterior realm, to draw the line between the possessor of the secret and the non-possessor. Demands to open up secrecy to the 'light of day' are integral to its success. By focusing on revealing the texts, critics and proponents helped to create two separate realms, aiding the effectiveness of secrecy as a tool of statecraft.

After discussing the scholarly literature, I turn to the historical trade politics of the TPP. Since the United States formally joined in 2010, attempts to control and manage the release of the documents increased. I suggest this is because the United States views the TPP as principally a foreign policy tool and not solely a favourable commercial agreement. Being the largest and most powerful negotiator in the talks, the United States set the trade agenda and reframed the TPP in geostrategic terms to reflect its concerns. The other negotiating states that are party to the talks tacitly agreed to this policy aim, and were party to the conceptual framework and practices of secrecy to protect the TPP. Likewise, this complicity extended to supporters of the TPP, most notably some members of the private sector as well as academics, journalists and officials.

I then shift focus to a close reading of the debate about the трр secrecy debates as they unfolded in New Zealand, where the Ministry for Foreign Affairs and Trade (MFAT) is the designated depository of the TPP texts; and, where TPP criticism has been prolific. I will draw on the New Zealand High Court case (Kelsey $v$ Minister of Trade 2015) that was lodged by TPP critics against the Minister of Trade, Tim Groser, in August 2015 and on other commentary in 
order to explore the characteristics of the transparency debate and introduce some of the key actors involved.

In the final section, I suggest that what seemed to be a crisis of legitimacy was, on closer examination, part of the theatrical performance of secrecy and that this helped affirm the sovereign status of the negotiating states. Demands for transparency and arguments against opening the texts to the public both worked to assert the existence of a secret; investing power in its contents by creating an exterior position and assigning power to the 'keeper' of the texts, which are the negotiating states. I argue that this focused attention on secret documents unwittingly left critical questions related to the militarisation of the Asia-Pacific region hanging.

\section{LOCATING THE STATE SECRET}

The state as a mythical and mythologising phenomenon has been analysed by many influential scholars in anthropology and the social sciences (Abrams 1988; Aretxaga 2003; Corrigan and Sayer 1985; Herzfeld 2005; Foucault 1991; Mitchell 1991; Taussig 1999; Trouillot 2001). Taking Foucault (1991), Abrams (1988), and Corrigan and Sayer (1985) as points of departure, my analysis of the literature has generated insights into how states are less coherent, all-powerful entities that are above and beyond society than they are assemblages of mundane disciplinary practices (Foucault 1991, 02). These practices are what produce the 'spurious unity of the idea of the state' (Abrams 1988, 79) and give it the institutional solidity and gravitas that it repeatedly proclaims. As Corrigan and Sayer (1985) remind us, 'the state never stops talking' (3). It has to do this to disguise the struggle, to 'legitimise the illegitimate' that is the 'insupportable and intolerable' domination and arbitration over life that it ascribes itself (Abrams 1988, 76).

Mitchell's work $(1991,1999)$ is particularly instructive in his articulation of the critical role that differentiation plays in constructing the 'real official secret... the secret of the non-existence of the state' (Abrams 1988, 77). Mitchell builds on both Abrams and Foucault to stake out a case for closely examining the practices that create the presumed state-society separation. He reminds us that the 'power to regulate is not simply a capacity stored within a state, from which it extends out into society' (Mitchell 1999, 102). According to Mitchell this outward projection of power is an illusion: there is no state standing outside or above society. Ferguson and Gupta (2002) elaborate on Mitchell to argue that the spatial practices of 'verticality' and 'encompassment' are key to naturalising the authority of states as 'superior centres of power' (2002, 982). 
This set of spatialising metaphors is loaded with assumptions about hierarchy and control. At the apex of vertical height and with breadth beyond the local, the state is situated as the sole, legitimate authority. Ferguson and Gupta (2002) emphasise how this abstracting process positions the state and its agents, officials, as holders of the singular right to act on behalf of the general will of the nation: only representatives of the state can know and understand the population, the nation, and its economy (Foucault 1991; Mitchell 1991, 1999). The local, with its limited view and particularistic interest, is pitted against the superior ocular powers of the state.

The productive capacity of the secret, its tendency to separate people and inspire deference of its contents through performance, makes it an ideal tool in the ongoing process of state formation. Simmel (1906) and Durkheim (1915) laid the foundation for sociological and subsequent anthropological understandings of the work of secrecy. Their psychosocial insights on religion and secret societies, particularly the focus on the saliency of performance and the capacity of secrecy to differentiate, continue to be insightful and inform many anthropological accounts of secrecy, including my own (Masco 2010, 2014; Mahmud 2012a, 2012b, 2014; Luhrmann 1989; Nugent 2010; Taussig 1999).

In his essay, Simmel (1906) details how control by creating a separation between the 'internal' and the 'external' world is an intrinsic characteristic of secrecy: 'secrecy and pretence of secrecy (Geheimnistnerei) are means of building higher the wall of separation' (486). Yet, as Simmel (1906) and Durkheim (1915) point out, if the veil of separation is lifted and the disguise-secret is revealed, the deep significance of the secret loses its inner meaning, its profundity, and its power. The power of the secret is in its political deployment as an idea, not solely in its substance. Luhrmann (1989) picks up on Simmel and draws our attention to the magic of the secret, adding that 'concealing information about a subject can reinforce the belief in its claims' (137). The inference that secrets are too powerful to share and must be managed exaggerates the sense of separation between the possessor of the secret and the non-possessor. The non-possessor is provoked by the mystery and ambiguity of the secret to invest the secret, and its possessor, with deference and awe even if indifferent to the secret.

The focus on the imperative to reveal the hidden truth of secrets can be easily fetishised. This is a crucial aspect to secrets: to elicit suspicion and a belief in its potential power. Transparency closely linked to secrecy purports to disclose the truth, but this pledge to reveal what is hidden, is an ideological demand that is not as neutral as it is often presented by the adherents and applicants of 
this discourse. Underpinning the logic of transparency are modernist claims to higher reason and rationalism (Comaroff and Comaroff 2003; West and Sanders 2003) wrapped up in contemporary beliefs about the superior function of markets to objectively measure and assess (Power 1997; Shore and Wright 2015; Strathern 2000a).

In many ethnographic accounts, transparency is defined as a technique to improve the health of organisations and institutions (Garsten and Jacobsson 2011; Garsten and Montoya 2008; Shore and Wright 2015). This reflects the adoption of neoliberal ideas in order to increase public scrutiny (see Dean 2002; Florini 2007). Anthropologists, however, have also suggested that the current interest in transparency - that it can deliver on its promise to reveal truth and restore democracy - fails to see the limitations of how transparency works in practice (Mahmud 2012a; Schumann 2007). Strathern (2000) suggests that by highlighting the lack of security, knowledge, and accountability, repeated calls for transparency simultaneously amplify distrust. To ameliorate this, more verifiable information is sought, and transparency appears to have no end.

Mazzarella's (2007) ethnographic study of Indian corruption scandals highlights how the focus on revealing secrets can, in fact, divert public attention away from 'more disturbing arenas and events' (2007, 470). According to Mazzarella, the public can get drawn into the game of revelation and obsessively desire to see what lies behind secrecy. He argues that this compulsion aided and abetted the mysticism of the Indian state. Similarly, obsessing over the substance of the secret can act to disguise the failure of democratic politics, and calls to reveal the secret can become a surrogate for direct political action and an energised citizenry (Birchall 2011; Dean 2002; Masco 2010), 'The democratic state form, which presents a formal claim to transparency and accountability, has been reduced, via the logic of the secret, to a fight over the terms of the non-visible rather than social progress' (Masco 2010, 451).

Research has shown that the state draws on secrecy because of its capacity to differentiate, control, and animate the social (Horn 2011). Distrust about what is not being seen is an essential part of the secret's workings (Barrera 2013). In the case of the TPP, as it has played out in New Zealand, the calls for transparency have been underpinned by a suspicion that the TPP is part of a broader project to expand corporate power. Before I turn to detailing these demands to release the TPP text, I provide background information about how the secrecy surrounding the TPP increased following the reformulation of US policy in the Asia-Pacific. 
After World War II, the United States and Britain drafted the General Agreement on Tariffs and Trade (GATT) by defining and enforcing a multilateral system of liberal trade rules based on neoclassical economics. The purpose of GATT was to stave off protectionism, aid reconstruction, and encourage the development of capitalist economies. Stability and peace were directly linked to prosperity. From the outset, the United States used GATT as a forum to pursue its national foreign policy aims, reframing GATT within the context of the Cold War. The TPP agreement mirrors similar efforts by the US in GATT to fuse foreign policy with trade. For this reason it is important to analyse the TPP not only as a tactical response to the demise of multilateralism, and as a commercial agreement, but also as an extension of the United States' external security concerns. By tracing the geostrategic aims of the US, we can start to see the contours of the secrecy surrounding the TPP.

The early GAT T rounds, from Geneva to Tokyo (1948-1979), achieved significant cuts in tariffs on manufactured goods. The focus on reducing border tariffs during this period reflected the export interests of GATT members, particular the US and Europe. Membership had started at 23 and had expanded to 102 by the time of the Tokyo Round, making consensus in the early rounds relatively easy to forge. This was partly also because decision making was centred on bilateral negotiations with the United States. The composition of membership reflected liberal democratic values and geopolitical concerns about the threat of communism and non-capitalist state models (McKenzie 2008). The approach by GATT members was to either exclude communist states such as China and Hungary or to include states to attenuate their link with the Soviet Union, bringing them closer to the Western Alliance. The US viewed trade as a mechanism to induce political alignment. For example, in the debates on Japan's accession in 1958, the US persuasively argued that Japan risked falling into the 'Soviet orbit' if not allowed to join (McKenzie 2008, 95).

By the start of the Tokyo Round (1973-1979), the US had moved from a trade surplus to a deficit. Blame was laid on increased export competition from Japan and East Asia as well as non-tariff barriers (NTBs). These NTBs included, for example, export subsidies, customs procedures, and regulatory standards, and were seen to discriminate against US multinational firms. In response, the US slowed further tariff reductions in subsequent GATT rounds, instead insisting that negotiations focus on NTBs and other behind-the-border issues that impeded the flow of services and investments. This shift marked the beginning of a new trade era in which the US and other Western industrial states began 
progressively to push for deep liberalisation and not just tariffs on manufactured goods (Hocking and McGuire 2004). However, as GATT membership grew to include more developing countries, it became more difficult for the US to achieve its policy aims. Developing countries refused to reduce their regulatory barriers without first seeing decreases in tariffs on labour-intensive goods such as textiles and apparels and in agricultural subsidies.

In 1995 the World Trade Organisation (wто) replaced GATT following the conclusion of the Uruguay Round (1986-1994). Furthermore, membership had expanded to 128 . The intention of the wTо was to address the shortcomings of GATT by shoring up the dispute settlement process and redressing the power imbalances between developed and developing countries. The WTO achieved some reforms but failed to attend to criticisms that the multilateral system favoured Western industrial states, most notably the US. This persistent neglect led to the spectacular collapse of talks in Seattle in 1999. In 2001 the wTо attempted to reignite talks at Doha, but these have been stalled since 2003. Frustrated with the WTO stalemate and facing a weaker negotiation position because of the emergence of BRICs economies (Brazil, Russia, India, and China), the US began to turn away from multilateralism and enter into bilateral and plurilateral free trade agreements (FTAs) as an alternative avenue to pursue foreign and trade policy.

From an economic perspective, these FTAs were part of a broader strategy to force others to liberalise by creating the threat of trade and investment diversions. Ultimately, the goal was to create a critical mass of FTAs that would spill over to the што and rewrite the terms of multilateral trade in the United States' interests. However, security concerns played a significant part, particularly in the selection of FTA partners (Capling and Ravenhill 2011; Griffith et al. 2015). This pattern of using preferential agreements as vehicles to support geostrategic objectives can be traced back to the Israel-US FTA in 1985. However, after the September 11 terrorist attacks in 2001, the US stepped up its use of FTAs and entered into agreements to reward existing strategic relationships (for example, with Australia, Chile, Singapore, Morocco, Jordan, and Oman) and to punish others that were unwilling to support the Iraqi war (for example, New Zealand). The TPP is the latest and most explicit expression of the United States' policy to use FTAs as foreign policy tools.

In 1995 officials from New Zealand, Singapore, and Chile, and later Brunei, worked together to draft the template for a Pacific wide plurilateral agreement as an alternative to the moribund WTO and the ineffective APEC. The primary aim of the $\mathrm{P}_{4}$ (Pacific Four) was to entice the US and other major Asia-Pacific 
states into a mega-FTA, the idea being to create a high-quality, comprehensive regional agreement, and a forum for deep liberalisation (Lim, Elm, and Low 2012). Distracted by Iraq and Afghanistan, the US only became interested in joining the TPP as military operations in the Middle East were winding down in 2008. This coincided with the election of President Obama and the emergence of foreign policy initiatives to strengthen American leadership in the Asia-Pacific region. In 2010 the US formally joined the TPP. Membership also grew, and by 2015 twelve states were involved: New Zealand, Singapore, Chile, Brunei, Australia, Malaysia, Vietnam, Peru, Mexico, Japan, Canada, and the United States.

Rhetoric initially centred on how the TPP would ensure that the US was economically plugged into the Asia-Pacific region and could level the playing field for its multinationals. But in 2011 and 2012, the emphasis shifted to military and security concerns and the TPP was reconfigured as the commercial component of the Obama administration's new plan to intensify its diplomatic and strategic presence in the Asia-Pacific. Underlying this 'pivot' (see Clinton 2012; Manyin et al. 2012) towards the Asia-Pacific was China's growing economic influence, its military capabilities, and the territorial disputes in the South China Sea. The US viewed Chinese military assertiveness as a direct challenge to its naval hegemony in the region. During this period, the трр became a means to fortify foreign policy efforts: not only could it cement key strategic relationships and promote market capitalism over state-led capitalism, but symbolically the TPP could reposition the US as an Asia-Pacific state, engaged and ready to compete with China for political and economic dominance over the region. The technical trade-liberalising aspect of the TPP remained crucial, but the importance of the agreement lay more in its impact on regional and global politics. As United States Trade Representative (USTR) Ambassador Michael Froman stated in June 2014:

TPP is a central component of America's rebalance to Asia. At a time when there are unresolved territorial and maritime disputes, TPP can reinforce our presence in the region and our interest in establishing methods of cooperation and mechanism for resolving frictions. At a time when there are crises on multiple fronts, TPP can demonstrate that the United States is and always will be a Pacific power and be a concrete manifestation of our enduring commitment to the region. At a time when there is uncertainty about the direction of the global trading system, the TPP can play a central role in setting rules of the road for a critical region in flux ... the economic case for trade is the longest pole in the strategic tent, but the tent extends well beyond 
economics. U.S. trade policy is a central part of what may be the most consequential strategic project of our time: revitalizing the post-World War II international economic order.

One of the key features of US participation in the TPP has been the explicit articulation by officials and politicians of its strategic objectives, particularly with regard to China. Through presidential and executive speeches, press announcements, diplomatic attendance at multilateral and bilateral forums, and military exercises in the Pacific, the US has described its security and trade aims and the implications should negotiations fail. In an interview with the Wall Street Journal in April 2015, President Obama cast China as the existential threat to middle-class America, stating that if the United States does not 'write the rules' of the 'global economy', China will fill the vacuum with its own free trade deal in which 'American businesses will lose and American workers will lose. ${ }^{3}$ On the Whitehouse webpage, the TPP is represented as a competitive race between America and China. ${ }^{4}$ The risk of not winning is stark: erosion of democratic values, workers' rights, human rights, liberties, and the environment. Although commentators have remarked that the TPP is open to China and is not about containing China, the threat of a dominant Chinese economy has been symbolically used to mobilise support for the TPP.

Soon after the US joined the TPP negotiations, the original negotiating states entered into a confidentiality agreement, and New Zealand became the official depository of all documents. This was formalised by an exchange in letters that stated that the negotiating parties agreed to hold the following documents in confidence for four years after the TPP came into force or the last round of negotiations had been completed: the negotiating texts, the proposals of each government, accompanying explanatory materials, emails related to substance of the negotiations, and any other information exchanges in the context of the negotiations. TPP critics have commented that this action, along with the small amount of substantive information that the negotiating states have released on the negotiations, has amounted to an unprecedented level of secrecy (Dovere 2014). Commentators have pointed out the restricted access to трР documents by members of the US Congress; representatives must go to a secure reading room in the basement of the Capitol Visitor Centre to view the texts. They are not permitted to take staff with them or leave with notes, and nor are they permitted to discuss the text in detail with anyone. ${ }^{5}$ Similar measures exist in other TPP states, including New Zealand. 
The restricted access to the TPP documents had a direct impact on my research which I had not anticipated. On arriving at work one morning, my manager swiftly led me into a meeting room, saying he needed to have an urgent word with me.

Manager: 'I had an odd call from Dave in the Trade Strategy team. You know him, don't you?'

Sasha: 'Yes, I know Dave well.'

Manager: 'Well', he replied, 'apparently Groser's office called him asking who Sasha Maher was and why was she trying to access High Court documents about the TPP?'

I was blindsided. The papers I had requested were lodged by TPP protesters seeking a judicial review over the state's refusal to release any trade texts under New Zealand's Official Information Act (oiA) ${ }^{6}$. I was simply asking to view these papers.

Sasha: 'Oh, those documents, they're publicly available you know. I was hoping to find out the rationale behind why the papers had been submitted. It's for my research about the transparency debates in the TPP, and it has nothing to do with my work here. I made that explicit in my email requests.'

Manager nodded: 'You don't have to justify this to me. I understand you're a researcher. Just use your Gmail or private email account in the future, not your work account.' [Field note, September 10, 2015]

A month after initially being refused the High Court papers, I received an email from the Ministry of Justice's assistant registrar in Wellington advising me that I could now obtain the documents: 'The Minister for Trade has filed his statement of defence; you can access this and the statement of claim' (email communication 2015). I sent a formal letter seeking the papers and received them later that day. The allegations and responses in the High Court papers laid out the notable characteristics of the transparency debate: preoccupation with the concept of a nation's best interest and a fixation on the procedural, legalistic, and technical aspects of the negotiations. The latest link in a long chain of similar endeavours to obtain TPP documents by making appeals to 
the public's right to know, ${ }^{7}$ the papers challenged Minister for Trade, Tim Groser's, blanket refusal to release information about the трP under New Zealand's Official Information Act (OIA).

In the statement of claim filed by the prominent TPP campaigner and Professor of Law, Jane Kelsey, Minister Groser is accused of acting against the purposes of the Act when he originally declined Kelsey access to TPP documents. In a letter to Kelsey, he cited sections 6 and 9 under the Act as grounds for not releasing the requested information. These sections refer to protecting New Zealand's economy, international relations, and national interests. Kelsey alleged that these reasons defeated the purposes of the Act: to encourage effective participation in policy making, promote accountability of state representatives; and, ensure that information is protected only if that protection is consistent with the public's best interest. In her estimation, public interest in the TPP outweighed the rationale to withhold information. Kelsey and Groser's differing viewpoints on what comprises public interest roughly represent the two opposing sides of the TPP debate.

The groups and individuals who strongly support the TPP are generally diplomats, officials, politicians, corporate representatives, and export-orientated industry associations. For example, in New Zealand its supporters included National Party politicians, some members of the Labour Party, officials from MFAT, the NZ-US Council, the NZ International Business Forum (NZIBF), and agricultural exporters, including my employer, Fonterra. They believe that the state should act as a good landlord, ensuring that investors' needs are attended to in order to attract and retain foreign and domestic capital. Conceived in this way, the state's main responsibility is to regulate and continuously police the market in order to safeguard economic activity. The state should not participate in the market; rather, its purpose is to provide the political, legal, and institutional framework to enable unhindered competition, from which economic benefits are thought to eventually flow back to citizens in the form of employment opportunities, more efficient services and consumer choice. The TPP agreement promises to deliver these conditions by imposing limits on state actions where these may distort optimal market dynamics. They argue that the interests of the public are best served by the state defending the market from intervention, thus ensuring that the TPP is successfully completed to a high standard. Proponents believe that the state is correct to withhold TPP documents from public access: to release these earlier risks destabilising the talks, and undermining the public interest. The focus by supporters is on the economic aspect of the TPP not the geostrategic. 
In contrast, critics of the TPP see the state in Keynesian, nationalist terms (see Jessop 1990). These critics are broad ranging and include: rights-based groups, Māori, NGOs, political parties and organisations, unions, and industry associations that are domestically focused. The leading oppositional voices in New Zealand include Professor Kelsey, Oxfam, Greenpeace, It's Not Our Future, The Green Party, multiple Māori iwi, and the New Zealand Council for Trade Unions. According to TPP critics, the primary function of the state is to implement policies and intervene in the market in order to maximise the social and economic welfare of its citizens, not that of foreign investors or firms. For TPP critics, then, the TPP agreement threatens to erode national sovereignty by imposing limitations on the behaviour of states and its capacity to select policies. Similar to proponents, critics see the state as representing the nation, but they argue that the state is obliged to make TPP documents accessible to citizens.

Political differences aside, TPP critics and proponents both share statist or legalistic perspectives of the state and are mainly concerned about upholding the public interest. They agree that the rightful role of the state is to govern people and make decisions on the behalf of the nation. The state is construed as a sovereign entity that stands above and governs the hierarchically lower spheres, which comprise interests. The state's only concern is the objective assessment of these wider interests, which are understood in the cumulative sense as the national interest or the public interest. Cast in the form of an authoritative person, the state not only holds the superior capacity to know the interests of all citizens, it is assumed that it should control this knowledge because only the state can adjudicate objectively on behalf of the nation. The lower interests are often referred to as vested and are framed as suspicious, narrow, and deleterious to the overarching public interest.

Kelsey interpreted the public interest to be best served by releasing the text in order to expose the influence of 'vested' corporate interests. Minister Groser believed that disclosure would seriously damage the public interest by threatening to undermine the трP by arousing unnecessary opposition. His view was that 'vested' interests were not the corporate advisors, as Kelsey had suggested, but critics of the TPP. In an interview with the business press, Groser commented on the transparency calls from TPP critics:

Those people who are opposed to the agreement want access to the texts so they can blow it apart ... They're not asking for transparency, quote unquote, because they really want to see the texts carefully and contribute to a good discussion. They want to screw the negotiation and destroy it. ${ }^{8}$ 
Despite the divergence in the transparency debates, both critics and proponents attributed the state with the capacity to know and the authority to withhold (or disclose) information on the TPP documents. This reinforced the idea that TPP documents contained powerful information. But it was not only the state to which agency was attributed in the transparency debate. TPP critics also depicted multinational corporations as monolithic, standalone entities capable of corrupting negotiators and trade policy. In New Zealand the suspicions that underwrote the dominant transparency discourse framed multinationals as shadow directors to the TPP. TPP critics such as Kelsey hoped to reveal the collusion with corporates so that democracy could be restored.

The critics' widespread distrust with the negotiation process was fuelled by whistle-blower organisation Wikileaks, which published three тPP chapters between 2013 and 2015 and issued a US $\$ 100,000$ reward for whoever leaked the other 26 chapters. ${ }^{9}$ However, the highly publicised leaked chapters did not reveal any new knowledge about the power corporates, and neither did they remedy the imbalance in the negotiating process by opening up space for greater public participation (see Estop 2014). The leaks exposed nothing but what was already known about the TPP: that the agreement sought to institute a suite of regulatory changes to protect capital flows and assets.

Notwithstanding the banality of the Wikileaks leaks, the idea of classified information being leaked enhanced the importance of the secret in the minds of many New Zealanders, deepening belief in the existence of secret information, and hardening the resolve to disclose its contents. Opponents became invigorated against the state, arguing that the leaks proved that the New Zealand officials had capitulated to corporate interest, particularly from the US. For example, following Wikileaks' release of the investment chapter in 2015, opposition voices rallied across New Zealand's multimedia exclaiming 'New TPPA investment leak confirms NZ surrender to US, ${ }^{10}$ 'Today's leaked text confirms all our worst fears.... As anticipated, the deal gives foreign investors from the TPPA countries special rights, and the power to sue the government, ${ }^{11}$ and '.. leaked TPPA chapters shows it up as a 'corporate gangster shakedown." ${ }^{12}$ Yet as noted in previous fieldwork (Maher 2012), at least in the New Zealand context, corporate influence during the TPP negotiations was moderated by the degree with which specific demands supported the dominant neoliberal policy agenda. This interpretation lay with trade officials who also controlled information and participation at formal and informal government-business events such as the NZ-US Partnership Forums.

The response from TPP proponents, particularly politicians and representa- 
tives of the private sector, has been to deny that there was any secrecy: they have argued that 'privacy' and 'discretion' are simply a part of the negotiating process and that multiple stakeholder sessions have taken place. For example, in his statement of defence, Groser's reply to Kelsey's accusation that he unlawfully withheld papers under the oIA was simply to state that 'the Ministry of Foreign Affairs and Trade had provided as much information as possible, consistent with New Zealand's best interests and the confidentiality arrangement' (Kelsey v Minister of Trade 2015, 4). Such measured responses, bereft of details and delivered in a reasoned manner, are common. On the MFAT's website page dedicated to the TPP, concerns about secrecy are made by appealing to bureaucratic rationality:

In the past, New Zealand has usually published free trade agreement texts at the time of signature. This was the approach taken in the case of the $\mathrm{P}_{4}$, China, AAnZfTA, Hong Kong, Malaysia and AnZTEC agreements for example. In the case of TPP we expect the text of an agreement will be released before it is signed by TPP governments. New Zealand supports this approach for TPP reflecting public interest in the agreement and the domestic requirements of other countries. Exactly when the text will be published following the conclusion of negotiations will need to be agreed by all TPP countries. ${ }^{13}$

This same deliberate response appears in statements from corporates. For example, in an address to the Institute of International Affairs (IIA), the Executive Director of the NZ International Business Forum (NZIBF) dismissed the question of secrecy, stating that a more open process would inevitably lead to vested interests seeking to undermine the negotiation and that the New Zealand Government was simply following the established constitutional practice. ${ }^{14}$ Yet for many critics, the repeat reference to the treaty policy process does not constitute effective or meaningful participation. This is because public debate about the details of the тPP can only occur once all трP states have reached consensus. In New Zealand, the Executive has the power to sign treaties: Parliament only passes the enabling legislation required to put the agreement into place. Despite criticism of the deficiencies in the treaty-making, the refrain from proponents has been to insist that enabling Parliament to view the agreement will in time allow for considered, balanced discussions. An outcome from the consistent attention on the procedures in the transparency debates has been to ensure focus remains safely on the policy making process and not the geostrategic elements of the TPP. 
In the TPP debates, critics, provoked by the potential for the TPP to impinge on domestic policies, focused on the withholding of TPP documents, labelling the negotiations as secretive. Their opposition promoted suspicions that the texts were being kept secret because if exposed they would reveal the truth that the TPP states had acquiesced to the demands of multinationals. The TPP, therefore, did not represent the nation's best interest but had been captured by corporate, vested interests. Although this tactic can be traced back to past trade negotiations, including the Seattle wTO riots and, most recently, the Anti-Counterfeiting Trade agreement (АСТА), during the трP negotiations, it become a central focal point for protestors.

I argue, however, that although demands for transparency were successful in opening up a space for oppositional politics and creating an engaged public, it also inadvertently amplified the power of the secret and aided its capacity as a technique for state formation. The debate, as it unfolded in New Zealand worked to affirm the legitimate authority of the New Zealand state as rightful protector of the national interest. The debates produced a sceptical public, but the singular focus on transparency partially obscured other aspects of the agreement.

Secrets are part of the toolbox of state formation (Horn 2011). Secrecy creates separation, insiders and outsiders that are then hierarchised (Simmel 1906). When used as political technology, the secrets become a means to differentiate society from the state, a means to produce a structural effect of a unified, abstract agent that looms over and above society (Ferguson and Gupta 2002; Foucault 1991; Mitchell 1991, 1999). In the heated discussion about releasing the texts, critics and proponents alike drew this line of separation and cast the state as a higher being. Both confidently asserted that the state's duty was to manage information and negotiate on behalf of the nation, disagreeing only about the amount of information to which the public should have access. Along with the proponents, the critics supported the claim that the state should not be swayed by external vested interests. In the eyes of the critics, the vested interests were the corporates, whereas the proponents saw the critics as threats to the sanctity of the national interest.

Although there is a close association, and frequent consultation between corporates and trade officials, particularly in the US context in which it is legislated under the Trade Act of 1974 (Destler 2005), it would be inaccurate to assume that negotiations follow corporate demands. The degree of influence 
depends on the framework for stakeholder consultations, and the historical and political context of business-government relations. Based on previous fieldwork carried out in the US and New Zealand on the TPP (Maher 2012), I have shown that some but not all private sector organisations have considerable access to trade officials in formal and informal settings, and as such the more powerful companies are given the opportunity by officials to articulate their positions in unofficial contexts. They are also often asked for technical advice. However, in TPP negotiations, corporates were forbidden from being inside the negotiation room and the decision-making and trade-offs remained with the officials. Rather than the outcome of principal-agent modes of interaction, trade texts should be viewed as complex struggles and compromises between many different individuals and groups, each with their own personal, ethical and political-economic interests. In the case of the тPP, corporate representatives were present and influential but relied on officials to agree with their positions within the context of more pressing, overarching policy aims.

How the transparency debate played out in New Zealand is instructive. While arguments swirled around about procedures and sovereignty, in 2010 and 2012 the state signed two momentous strategic agreements with the United States. The first, titled the Wellington Declaration, laid the foundations for regular high-level political and military dialogue and enhanced practical cooperation. ${ }^{15}$ This agreement helped to establish the second more significant agreement, the Washington Declaration. ${ }^{16}$ Essentially a defence pact, the Washington Declaration created a new framework to shape and execute defence activities in the Asia-Pacific, including those related to counter-terrorism, counter-proliferation, anti-piracy, maritime freedom, and resource exploitation in the region. As a consequence, and as outlined in the New Zealand Defence Force's 2012 strategy document, 'Future 35', New Zealand now engages in regular bilateral and multilateral military operations with the US and its allies, and has overtly increased its militaristic presence in the Pacific. ${ }^{17}$ An implicit part of the TPP deal has been this stepping up of security duties on behalf of the US to counter growing Chinese influence in the South Pacific. Yet in the debates about the TPP, opposition and supporters unwittingly left unaddressed critical questions pertaining to the security and defence implications of signing up to the TPP. As a result, not only have the potential negative effects on Pacific Island people not been considered, but public inquiry into New Zealand's ostensible independent foreign policy also remains absent.

EPILOGUE

The Kelsey $v$ The Minister of Trade judgment was released 13 October $2015 .{ }^{18}$ It 
quashed Minister Groser's decision, stating that he acted unlawfully by withholding some of the information Professor Kelsey requested. The judicial review ordered MFAT officials to assess each piece of information asked for against the Official Information Act 1982. The Ministry is yet to carry out this review and it is unlikely Minister Groser will appeal the judgment. The applicants' original intention to seek these official papers in February 2015 was to expose an assumed hidden agenda behind the TPP: the corporate influence and compromises on national sovereignty. Its timing was to coincide with the final round of negotiations. However, due to the Minister's initial refusal and subsequent lengthy judicial review process, this motive shifted to using the case as further evidence of how negotiations had been conducted undemocratically.

Only three weeks preceding the High Court judgment, on 5 October 2015, the TPP negotiations were formally concluded. A month later, New Zealand as depository, released the final TPP document which comprises over 6,000 pages and 30 chapters. ${ }^{19}$ Despite the negotiations coming to an end, the criticism about the lack of transparency remains audible, and although the final text is publicly available, all background material will continue to be held in confidence for four years. Critics are currently analysing individual chapters and efforts will now focus on the next phase of the treaty-making process as it moves through parliaments towards ratification.

NOTES

1 Sasha Maher is an Honorary Research Fellow of the Department of Anthropology at the University of Auckland New Zealand. She received her doctorate in Anthropology and Management from the University of Auckland in 2012. She currently works at Fonterra Co-operative, in the Commodity, Risk and Trading team. Her research interests include free trade politics and the anthropology of risk, and she is currently completing a second publication on trade agreements in the Pacific.

Email: sasha.e.maher@gmail.com.

2 I use the acronym 'TPP' as opposed to the 'TPРA' because in official documents TPP is used.

3 See http://blogs.wsj.com/washwire/2015/04/27/wsj-interview-transcript-president-obama-on-tpp-china-japan-pope-francis-cuba/ (accessed July 3, 2015)

4 See https://www.whitehouse.gov/issues/economy/trade (accessed October 10, 2015) 
5 The secrecy practices surrounding the TPP have been replicated in another regional free trade agreement the United States is negotiating with the European Union, the Transatlantic Trade and Investment Partnership (тTіP).

6 New Zealand's 1982 Official Information Act (OIA) was part of a wave of similar freedom of information legislation introduced during the 1980s and 1990s to make governments work more effectively. By permitting access to documents, ministries and agents of the state could be regulated and disciplined if the documents revealed inefficient, poor, or costly decision making. The orA in New Zealand was part of a wider package of state sector reforms that sought to institute neoliberal approaches to governance.

7 See https://www.eff.org/deeplinks/2014/12/demanding-us-trade-negotiatorspublish-their-public-records (accessed August 4, 2015)

8 See http://www.nbr.co.nz/article/calls-tpp-transparency-are-code-destroying-itsays-groser-bd-151763 (accessed September 13, 2015)

9 See https://wikileaks.org/WikiLeaks-issues-call-for-10o-ooo.html (accessed September 30, 2015)

10 See http://itsourfuture.org.nz/new-tppa-investment-leak-confirms-nz-surrender-to-us/ (accessed July 3, 2015)

11 See http://www.scoop.co.nz/stories/PO1503/Soo313/new-tppa-investment-leakconfirms-nz-surrender-to-us.htm (accessed July 3, 2015)

12 See http://thedailyblog.co.nz/2015/o3/27/leaked-tppa-chapters-shows-it-up-asa-corporate-gangster-shakedown/ (accessed July 3, 2015)

13 See тPр Talk at http://mfat.govt.nz/Trade-and-Economic-Relations/2-Trade-Relationships-and-agreements/Trans-Pacific/1-TPP-Talk/o-TPP-talk-3aa-Dec-2012. php (accessed 20 September, 2015).

14 The speech can be read in full at http://www.tradeworks.org.nz/tpp-where-tofrom-here-and-how-did-we-get-here-anyway-2/ (accessed on 2 September, 2015).

15 The Wellington Declaration can be viewed at http://www.mfat.govt.nz/Mediaand-publications/Features/665-Wellington-declaration-on-new-NZ-US-partnership.php (accessed 8 November, 2015) 
16 The Washington Declaration can be viewed at http://media.nzherald.co.nz/ webcontent/document/pdf/201225/washington\%2odeclaration\%20on\%2odefense\%2ocooperation.pdf (accessed 8 November, 2015).

17 Although not mentioned in Future 35, a clear line can be drawn between the contents of this document and the Washington Declaration both of which were completed in 2012.

18 The full judgement and all associated legal documents can be accessed on Professor Kelsey's website https://tpplegal.wordpress.com/legal-challenge-to-secrecy/ (accessed 13 November, 2015).

19 All publicly available TPP texts can be found on New Zealand's Ministry of Foreign Affairs and Trade's website http://tpp.mfat.govt.nz/text (accessed 13 November, 2015).

\section{REFERENCES}

Abrams, P. 1988. 'Notes on the difficulty of studying the state'. Journal of Historical Sociology 1 (1): 58-89.

Aretxaga, B. 2003. 'Maddening states'. Annual Review of Anthropology 32 (1):393410.

Barrera, L. 2013. 'Performing the court: Public hearings and the politics of judicial transparency in Argentina'. PoLAR: Political and Legal Anthropology Review $36(2): 326-340$.

Birchall, C. 2011.Transparency, Interrupted Secrets of the Left. Theory, Culture \& Society 28 (7-8): 60-84.

Capling, A., and J. Ravenhill. 2012. 'Multilateralising regionalism: what role for the Trans-Pacific Partnership agreement?' The Pacific Review 24 (5):533-575.

Clinton, H. 2011. 'America's Pacific Century: The future of geopolitics will be decided in Asia, not in Afghanistan or Iraq, and the United States should be right at the center of action'. Foreign Policy 189 (1):56-63.

Comaroff, J., and J.Comaroff. 2003. 'Transparent fictions: or, the conspiracies of a liberal imagination'. In Transparency and Conspiracy: Ethnographies of Suspicion in the New World Order, edited by. H. G. West and T. Sanders, 287-30o. 
Durham: Duke University Press.

Corrigan, P., and D. Sayer. 1985. The Great Arch: English State Formation as Cultural Revolution. New York: Basil Blackwell.

Dean, J. 2002. Publicity's Secret. How Technoculture Capitalizes on Democracy. Ithaca, N.Y.: Cornell University Press.

Dovere, E. 2014. 'Extreme secrecy eroding support for Obama’s trade pact'. http:// www.politico.com/story/2015/05/secrecy-eroding-support-for-trade-pactcritics-say-117581, accessed 17 September, 2015.

Durkheim, E. [1912] 1915. The Elementary Forms of Religious Life. New York: Free Press.

Estop, J. 2014. 'WikiLeaks from Abbé Barruel to Jeremy Bentham and beyond (A short introduction to the new theories of conspiracy and transparency)'. Cultural Studies, Critical Methodologies 14 (1):40-49.

Ferguson, J., and A. Gupta. 2002. 'Spatializing states: Towards an ethnography of neoliberal governmentality'. American Ethnologist 29: 981-1002.

Florini, A., ed. 2007. The Right to Know: Transparency in an Open World. New York: Columbia University Press.

Foucault, M.1991. 'Governmentality'. The Foucault Effect: Studies in Governmentality, edited by G. Burchall, C. Gordon and P. Miller, 53-72. Chicago: University of Chicago Press.

Froman, M. 2014. 'The strategic logic of trade' https://ustr.gov/about-us/policyoffices/press-office/speeches/transcripts/2014/June/Remarks-UsTR-Froman-at-Council-Foreign-Relations-Strategic-Logic-of-Trade, accessed 22 October, 2015

Garsten, C., and M. Lindh De Montoya., eds. 20o8. Transparency in a New Global Order: Unveiling Organizational Visions. Cheltenham: Edward Elgar Publishing.

Garsten, C., and K. Jacobsson. 2011. 'Transparency and legibility in international institutions: The UN Global Compact and post-political global ethics'. Social Anthropology 19 (4):378-393. 
Government of New Zealand.1982. Official Information Act 1982 http://www. legislation.govt.nz/act/public/1982/o156/latest/DLM64785.html, accessed 9 November, 2015.

Griffith M., R. Steinberg and J. Zysman. 2015. 'Great power politics in a global economy: Origins and consequences of the TPP and TTIP'. Conference Paper. University of California Berkeley, April 11.

Horn, E. 2011. 'Logics of political secrecy'. Theory, Culture \& Society 28 (7-8):103122.

Herzfeld, M. 2005. Cultural Intimacy: Social Poetics in the Nation-state. New York: Routledge.

Hocking, B., and S. McGuire. 2004. Trade Politics. London: Routledge.

Jessop, B. 1990. State Theory: Putting Capitalist States in their Place. Cambridge: Policy Press.

Kelsey $v$ Minister of Trade HC Wellington CIV-2015-485-583, 5 August 2015 (Statement of Claim).

Kelsey v Minister of Trade HC Wellington CIV-2015-485-583, 4 September 2015 (Statement of Defence).

Lim, C., D. Elms and P. Low., eds. 2012. The Trans-Pacific Partnership: a Quest for a Twenty-first Century Trade agreement. Cambridge: Cambridge University Press.

Luhrmann, T. 1989. ‘The magic of secrecy’. Ethos 17 (2):131-65.

McKenzie, F. 2008. 'GATT and the Cold War: Accession debates, institutional development, and the Western Alliance, 1947-1959'. Journal of Cold War Studies $10(3): 78-100$.

Maher, S. 2012. 'Leading From Behind: An Ethnographic Study of Business Diplomacy in the Making of Free Trade Agreements in New Zealand' Ph.D. dissertation, Department of Anthropology, Department of Management and International Business, University of Auckland. 
Mahmud, L. 2012a. 'In the name of transparency: Gender, terrorism, and the masonic conspiracies in Italy'. Anthropological Quarterly 85 (4):1177-1207.

- 2012b. 'The world is a forest of symbols: Italian freemasonry and the practice of discretion'. American Ethnologist 39 (2):425-38.

- 2014. The Brotherhood of Freemason Sisters: Gender, Secrecy and Fraternity in Italian Masonic Lodges. Chicago: University of Chicago.

Manyin, M., et al. 2012. Pivot to the Pacific? The Obama Administration's Rebalancing Toward Asia. Washington DC: Library of Congress Congressional Service https://www.fas.org/sgp/crs/natsec/R42448.pdf accessed 3 June, 2016.

Masco, J. 2010. 'Sensitive but unclassified: Secrecy and the counterterrorist state'. Public Culture 22(3): 433-63.

- 2014. The Theater of Operations: National Security Affect from the Cold War to the War on Terror. Durham, NC: Duke University Press.

Mazzarella, W. 2006. 'Internet x-ray: E-governance, transparency, and the politics of immediation in India. Public Culture 18 (3):473-505.

Mitchell, T.1991. The limits of the state: Beyond statist approaches and their critics. American Political Science Review 85 (1):77-96.

-1999. 'Society, economy, and the state effect'. State/Culture: State Formation after the Cultural Turn, edited by G. Steinmetz, 76-97. Ithaca: Cornell University Press.

New Zealand Defence Force. 2012. 'Future 35: Our strategy to the future'. Accessed 3 August, 2016 from , accessed 3 August 2015.

Nugent, D. 2010. 'States, secrecy, subversives: APRAP and political fantasy in mid2oth-Century Peru'. American Ethnologist 37 (4): 681-702.

Power, M. 1997. The Audit society: Rituals of Verification. London: Oxford University Press.

Schumann, W. 2007. 'Transparency, governmentality, and negation: Democratic practice and open government policy in the National Assembly for Wales'. Anthropological Quarterly 8o (3): 837-862. 
Shore, C., and S. Wright. 2015. 'Audit culture revisited'. Current Anthropology $56(3): 421-444$.

Simmel, G. 1906. 'The sociology of secrecy and of secret societies'. American Journal of Sociology 11 (4): 441-98.

Silverstein, P. 2002. 'An excess of truth: Violence, conspiracy theorizing and the Algerian Civil War'. Anthropological Quarterly 75 (4): 643-674

Strathern, M., ed.20ooa. Audit Cultures: Anthropological Studies in Accountability, Ethics and the Academy. London: Routledge.

- 20oob. 'The tyranny of transparency'. British Educational Research 26(3):309-231.

Taussig, M.1999. Defacement: Public Secrecy and the Labor of the Negative. Stanford, CA: Stanford University Press.

Trouillot, M. 2001. 'The anthropology of the state in the age of globalization: Close encounters of the deceptive kind'. Current Anthropology 42:125-138.

West, H., and T. Sanders., eds. 2003. Transparency and Conspiracy: Ethnographies of Suspicion in the New World Order. Durham, NC: Duke University Press. 